\title{
When free autogenous block grafts can lead to failure?
}

\author{
Tiburtino J. Lima-Neto ${ }^{1}$, Anderson Maikon de Souza Santos ${ }^{1}$, Mesk Samara $^{2}$, Stéfany Barbosa ${ }^{3}$, \\ Cecília Alves Sousa ${ }^{4}$, Leonardo Costa de Almeida Paiva ${ }^{5}$, Leonardo Perez Faverani ${ }^{1}$
}

${ }^{1}$ Oral and Maxillofacial Surgery, Department of Diagnosis and Surgery, Araçatuba Dental School, Univ. Estadual Paulista (UNESP), Araçatuba, São Paulo, Brazil; ${ }^{2}$ Department of Bioengineering, University of Illinois College of Dentistry, Chicago, IL, USA; ${ }^{3}$ Department of Dental Surgery, Araçatuba Dental School, Univ. Estadual Paulista (UNESP), Araçatuba, São Paulo, Brazil; ${ }^{4}$ Department of Dental Materials and Prosthesis, Araçatuba Dental School, Univ. Estadual Paulista (UNESP), Araçatuba, São Paulo, Brazil; ${ }^{5}$ Department of Oral and Maxillofacial Surgery, Hospital de Emergência e Trauma Senador Huberto Lucena, R. Orestes Lisboa, SN - Pedro Gondim, João Pessoa - PB, Brazil

Correspondence to: Tiburtino J. Lima-Neto. Oral and Maxillofacial Surgery, Department of Diagnosis and Surgery, Araçatuba Dental School, Univ. Estadual Paulista (UNESP), Rua José Bonifácio 1193, Vila Mendonça, 16015050 Araçatuba, São Paulo, Brazil. Email: tiburtinoneto@hotmail.com.

Received: 06 April 2020; Accepted: 26 August 2020; Published: 10 September 2020.

doi: $10.21037 /$ fomm-20-26

View this article at: http://dx.doi.org/10.21037/fomm-20-26

Most firearm fractures have a complex pattern of trauma involving comminution, bone loss and soft tissue avulsion (1). Projectiles hit the tissues with a high-energy impact, with the jaw being the most frequently affected body region (2). Secondary tissue damage leads to early ischemia and vascular impairment, which makes treatment difficult (1).

Rigid internal fixation has been the method of choice for the treatment of this type of fracture, as it provides stability, stress absorption and good bone consolidation, minimizing the occurrence of complications $(3,4)$. During surgical planning, a plate should be chosen that is strong and resistant to the functional loads exerted on the jaw and pay attention to an adequate number of screws (5).

Here, we bring a discussion about the failure of free autogenous block graft due to a lack of collaboration of the patient. Furthermore, a patient injured by a high velocity gunshot due to the characteristics of the fracture wound was initially treated incorrectly with only two screws placed on each side of the fracture in a $2.4 \mathrm{~mm}$ system plate, generating after 2 years a pseudoarthrosis picture characterized by pain, mobility and drainage of purulent discharge. Among the factors that can cause a pseudoarthrosis, the possible causes considered for this patient were the lack of union between the bone fragments, fracture site instability and tobacco use (6). Because it is a comminuted fracture with a large defect between the bone fragments, there is a need to perform graft surgery in an attempt to approximate it. To analyze the surgical opportunity, consider the situation of the underlying soft tissue and whether there are risks of infection $(4,5)$.
The patient was referred to the operating room, where infection was cleared, plate removed, pseudoarthrosis curettage, and then, a new plate was fixed. After cure of the infection soft tissue repair, the second surgical time was performed. Thus, at 6 months of follow-up with remission of the condition, it was decided to perform a graft with autogenous block graft, collected from the iliac crest. Although the micro vascularized graft is a good option for this case, it was not chosen because it is related to higher morbidity, requiring longer hospitalization and greater patient collaboration, which is not compatible with the patient's history (7-9). For the new fixation, a $2.4 \mathrm{~mm}$ diameter reconstruction plate was used, with at least three screws on each side of the fracture, in order to provide better stability and promote resistance to chewing forces (4,5) (Figure 1).

Besides being a difficult fracture resolution, the patient was not collaborative, not following the recommendations to avoid chewing and not to use tobacco and narcotics, which led to non-consolidation of the bone graft. Tobacco use increased the odds of complications four-fold and the odds of infections six-fold. This was associated with its ability to lead to delayed healing, decreased collagen production, decreased oxygen supply to tissues, and increased risk of complications. mesenchymal cell degeneration (10).

After 6 months of follow-up, the patient developed a new infectious condition and was reoperated to remove the graft and remained with the fixation system in position, awaiting the opportune moment for the second graft. $\mathrm{He}$ was followed for 1 year after graft removal, remaining uneventful. But without collaboration for planning and 

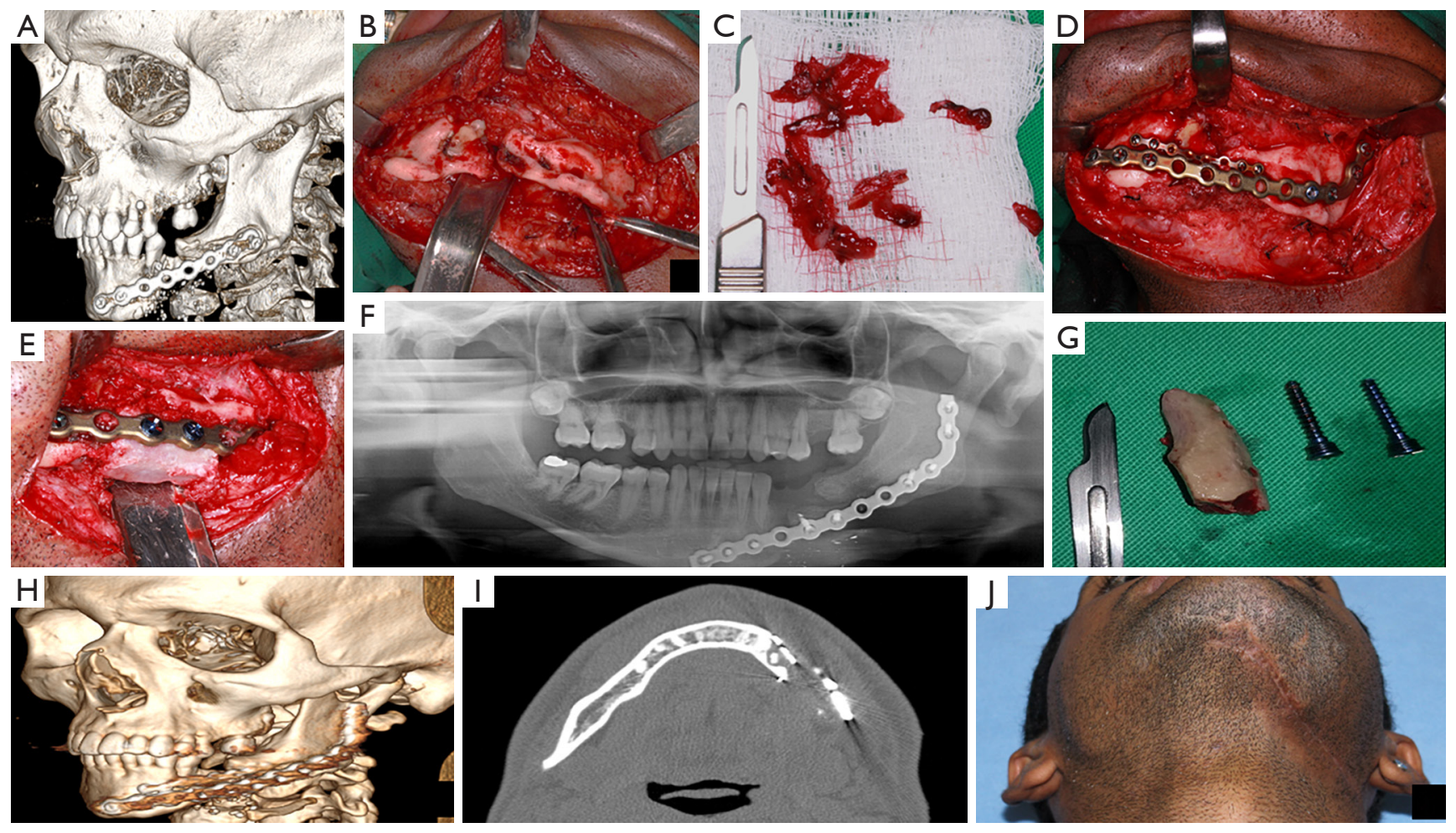

Figure 1 Case presentation. (A) Preoperative tomography showing incorrect fixation, $2.4 \mathrm{~mm}$ fixation system with two screws in each fractured; (B) trans-operative, there is a lack of continuity between fractured bone; (C) tissue removed from the region between the stumps (pseudarthrosis); (D) new fixation employing at least 3 screws on each side of the fractured bone; (E) iliac crest graft positioned and fixed with two screws of 2.4 $\mathrm{mm}$ locking system. Surgery performed 6 months after pseudoarthrosis removal; (F) panoramic radiograph, 6 months of follow-up, without new bone formation in the region; $(\mathrm{G})$ bone graft and screws removed after treatment failure; (H,I) tridimensional and axial sections tomography immediately after bone graft removal; (J) submandibular postoperative healing showing no infections or any complications.

execution of new treatment (Figure 1).

Therefore, mandibular fractures caused by firearms are a trauma that is difficult to treat, and it is essential to make proper planning and to collaborate postoperatively in order to avoid complications and restore mandibular function.

\section{Acknowledgments}

Funding: The authors would like to express gratitude for support from the Coordination for the Improvement of Higher Education Personnel (CAPES) in the PrINT Program (\#88887.373422/2019-00).

\section{Footnote}

Provenance and Peer Review: This article was a standard submission to the journal. The article has undergone external peer review.

Peer Review File: Available at https://fomm.amegroups.com/ article/view/10.21037/fomm-20-26/prf

Conflicts of Interest: All authors have completed the ICMJE uniform disclosure form (available at https://fomm. amegroups.com/article/view/10.21037/fomm-20-26/coif). The authors have no conflicts of interest to declare.

Ethical Statement: The authors are accountable for all aspects of the work in ensuring that questions related to the accuracy or integrity of any part of the work are appropriately investigated and resolved. Written informed consent was obtained from the patient for publication of this study and any accompanying images.

Open Access Statement: This is an Open Access article distributed in accordance with the Creative Commons 
Attribution-NonCommercial-NoDerivs 4.0 International License (CC BY-NC-ND 4.0), which permits the noncommercial replication and distribution of the article with the strict proviso that no changes or edits are made and the original work is properly cited (including links to both the formal publication through the relevant DOI and the license). See: https://creativecommons.org/licenses/by-nc-nd/4.0/.

\section{References}

1. Stefanopoulos PK, Soupiou OT, Pazarakiotis VC, et al. Wound ballistics of firearm-related injuries--part 2: mechanisms of skeletal injury and characteristics of maxillofacial ballistic trauma. Int J Oral Maxillofac Surg 2015;44:67-78.

2. Bede SYH, Ismael WK, Al-Assaf D. Characteristics of mandibular injuries caused by bullets and improvised explosive devices: a comparative study. Int J Oral Maxillofac Surg 2017;46:1271-5.

3. Ellis E 3rd, Graham J. Use of a 2.0-mm locking plate/ screw system for mandibular fracture surgery. J Oral Maxillofac Surg 2002;60:642-5; discussion 645-6.

4. Pereira CC, Letícia Dos Santos P, Jardim EC, et al. The use of 2.4-mm locking plate system in treating comminuted mandibular fracture by firearm. Craniomaxillofac Trauma

doi: $10.21037 /$ fomm-20-26

Cite this article as: Lima-Neto TJ, Santos AMS, Samara M, Barbosa S, Sousa CA, de Almeida Paiva LC, Faverani LP. When free autogenous block grafts can lead to failure? Front Oral Maxillofac Med 2020;2:21.
Reconstr 2012;5:91-6.

5. Alpert B, Tiwana PS, Kushner GM. Management of comminuted fractures of the mandible. Oral Maxillofac Surg Clin North Am 2009;21:185-92, v.

6. Pichardo SEC, Ten Broek FW, Richard van Merkesteyn JP. Treatment of pathologic fractures of the mandible in stage III medication-related osteonecrosis of the jaw-an observational study. J Craniomaxillofac Surg 2018;46:1241-6.

7. Mertens C, Decker C, Engel M, et al. Early bone resorption of free microvascular reanastomized bone grafts for mandibular reconstruction---a comparison of iliac crest and fibula grafts. J Craniomaxillofac Surg 2014;42:e217-23.

8. Gadre PK, Ramanojam S, Patankar A, et al. Nonvascularized bone grafting for mandibular reconstruction: myth or reality? J Craniofac Surg 2011;22:1727-35.

9. Fernandes BDR, Mendes BC, Mulinari-Santos G, et al. Strategy of mandibular central arch reconstruction after firearm injury. J Craniofac Surg 2019;30:e629-30.

10. Odom EB, Snyder-Warwick AK. Mandible fracture complications and infection: the influence of demographics and modifiable factors. Plast Reconstr Surg 2016;138:282e-9e. 